\title{
PERBEDAAN MODEL PEMBELAJARAN OPEN INQUIRY DAN GUIDED INQUIRY BERDASARKAN KEMANDIRIAN BELAJAR DAN BERFIKIR TINGKAT TINGGI PADA MATA PELAJARAN BIOLOGI KELAS 11 MAN TEMPURSARI - NGAWI
}

\author{
Novita Adiqka Putri ${ }^{1}$, Nurwidodo ${ }^{1}$, Yuni Pantiwati ${ }^{1}$ \\ ${ }^{1}$ Pendidikan Biologi FKIP Universtias Muhammadiyah Malang, \\ e-mail : nurwidodo88@yahoo.com
}

\begin{abstract}
Based on PISA (Programme for International Student Assessment) data which PISA is international studied about reading, math, and science literacy students achievement attained the age of 15 giving the result. In 2006 at Indonesia that students answer composition indicated lower understanding toward basic of science concepts (students could not interpret the data, explain casual relationship, solve the problems), limited expressing in mind, had lower scientific logical, lower ability toward basic of science concept and connection toward the surrounding facts. It is supported with lower teacher competency data and the usage of un-variation learning model. In that case, it is needed an learning model to solve the problem, one of learning model that can be used is Open Inquiry and Guided inquiry. In this present study, researcher used true-experiment by using simple random sampling technique. The purposes of this study are; (1) to know the differences study between Open Inquiry and Guided inquiry learning model, (2) to know the differences higher order thinking between Open Inquiry and Guided inquiry learning model. This research was hold in XI Science Class MAN TempursariNgawi. Independent Learningdata obtained based on temporary questionnaires, higher order thinking obtained by essay questions. The data analysis used by using one way Anova test. The result of this study showed that (1) Ftest $>$ Ftable, $5.805>4.07$ till the using of learning model give different result toward independent learning, (2)Ftest $>$ Ftable, $4.374>$ 4.07till the using of learning model give different result toward higher order thinking skill.
\end{abstract}

Key words: Inquiry, Open Inquiry, Guided inquiry, Independent Learning, Higher Order Thinking Skill.

Keberhasilan dalam pendidikan tidaklah lepas dari kegiatan proses belajar mengajar. Dalam proses belajar mengajar diperlukan suatu ketrampilan atau keahlian tertentu oleh guru untuk menyampaikan materi pelajaran. Belajar mengajar pada dasarnya adalah interaksi atau hubungan timbal balik antara guru dan siswa dalam situasi pendidikan. Oleh karena itu, guru dalam mengajar dituntut kesabaran, keuletan, dan sikap terbuka di samping kemampuan dalam situasi belajar mengajar yang lebih aktif (Utami, 2012)

Pembelajaran Biologi bertujuan untuk memahami hakikat Biologi. Hakikat Biologi adalah kumpulan konsep dan prinsip, proses memperoleh eksplanasi ilmiah fenomena alam, dan konteksnya dalam kehidupan sehari-hari. Pembelajaran Biologi memberikan pengalaman belajar pada siswa yang ditekankan melalui peran aktif dalam menemukan dan mengkonstruksi pengetahuannya. Piaget dalam Sanjaya (2010) menyatakan bahwa pengetahuan bukanlah hasil "pemberian" orang lain seperti guru, tetapi hasil dari "proses mengkonstruksi" yang dilakukan setiap individu. Oleh sebab itu, siswa yang secara aktif terlibat dalam proses pembelajaran dicirikan pada dua aktivitas yakni aktif dalam berpikir (minds-on) dan aktif dalam berbuat (hands-on). Pola Pembelajaran SMA lebih ditekankan bagaimana siswa tersebut dapat menganalisis, mensintesis dan mengevalusi pembelajaran melalui soal atau yang disebut dengan berfikir tingkat tinggi. Kemampuan berfikir tingkat tinggilah yang dinilai masih belum maksimal karena di beberapa instrument evaluasi belajar (soal) banyak dominan 
menggunakan kemampuan berfikir tingkat rendah.

Berdasarkan data dari PISA (Programme for International Student Assessment) yang merupakan studi internasional tentang prestasi literasi membaca, matematika, dan sains siswa sekolah berusia 15 tahun memberikan hasil di tahun 2060 di Indonesia bahwa komposisi jawaban siswa mengindikasikan lemahnya pemahaman terhadap konsep dasar sains (tidak bisa mengintreprestasi data, menerangkan hubungan kasual, memecahkan masalah), keterbatasan mengungkapkan pikiran, kemampuan nalar ilmiah masih rendah, lemahnya penguasaan siswa terhadap konsep dasar sains dan keterkaitan terhadap fakta-fakta disekitarnya (Kemendikbud, 2009).

Pembelajaran IPA Biologi lebih banyak menekankan siswa untuk bersikap kritis atau ilmiah. Oleh karenanya, penggunaan metode pembelajaran harus disesuaikan dengan kebutuhan dari pembelajaran tersebut. Salah satu metode pembelajaran yang sesuai dengan kontens pembelajaran Biologi adalah metode Inquiry. Inquiry merupakan suatu proses yang bermula dari merumuskan masalah, merumuskan hipotesis, mengumpulkan data, menganalisis data, dan membuat kesimpulan (Trianto, 2010). Kemampuan inquiry sering dikaitkan dengan kegiatan penyelidikan atau eksperimen.Pada kegiatan penyelidikan, siswa dapat mengkonstruksi pemahaman melalui pertanyaan, mendisain, dan menghubungkannya dalam bentuk investigasi, kemampuan analisis, dan mengkomunikasikan penemuannya. Salah satu prinsip utama inquiry, yakni dapat mengkonstruksi sendiri pemahamannya dengan melakukan aktivitas aktif melalui investigasi pengetahuan (Zein, 2007).

Metode inquiry dapat di bagi menjadi beberapa model. Salah satu model atau tipe dari inquiry adalah open inquiry (inquiry terbuka atau bebas) dan guided inquiry (inquiry terbimbing). Keduanya merupakan inquiry dengan tipe berbeda. Open inquiry lebih menekankan siswa untuk bekerja sendiri dari mulai mencari masalah hingga menemukan jawabannya sehingga kemandirian siswa sangat diperhitungkan. Sementara guided inquiry dalam proses pembelajarannya siswa masih mendapatkan bantuan dari guru atau guru melakukan pembimbingan pada siswa secara penuh. Dengan membandingkan keduanya maka akan diperoleh hasil yang beragam dalam pembelajaran. Open inqury dan Guided inquiry juga dapat digunakan menjadi tolak ukur kemandirian siswa. Proses pembelajaran siswa dihadapkan pada langsung masalah Sains atau Biologi yang banyak dijumpai dalam kehidupan sehari - hari. Sehingga metode pembelajaran inquiry dapat digunakan sebagai alternative metode pembelajaran.

Ardana (2000) mengemukakan bahwa paradikma belajar yang diinginkan abad pengetahuan adalah belajar berorientasi pada proyek, masalah, penyelidikan (inquiry), penemuan, dan penciptaan. Inquiry dapat mengajak siswa untuk mampu mengembangkan berbagai hipotesis dalam pikirannya, kemudian mampu berpikir divergen. Penggunaan model inquiry sangat berkaitan dengan peningkatan kemandirian siswa. Menurut Amin (2010) "membantu siswa untuk mandiri berarti menolong mereka dari bantuan orang lain". Penerapan sistem pembelajaran inquiry yang mana siswa mempunyai kewenangan penuh pada dirinya dalam menemukan konsep pengetahuan, merupakan bentuk peningkatan kemandirian yang bisa diterapkan pada siswa.

Berdasarkan uraian dan gambaran umum di atas maka peneliti akan meneliti tentang "Perbedaan model pembelajaran open inquiry dan guided inquiry berdasarkan kemandirian belajar dan 
berfikir tingkat tinggi pada mata pelajaran biologi MAN Tempursari Ngawi".

\section{METODE}

Jenis penelitian yang digunakan pada penelitian ini adalah penelitian True eksperimen atau eksperimen yang sesungguhnya.Menurut Sugiyono (2010) bahwa pada penelitian ini, peneliti dapat mengontrol semua variabel luar yang mempengaruhi jalannya eksperimen.Ciri utama dari true eksperimen adalah bahwa, sampel yang digunakan untuk eksperimen maupun sebagai kelompok kontrol diambil secara random dari populasi tertentu. Jadi cirinya adalah adanya kelompok kontrol dan sampel dipilih secara random. Desain penelitian yang digunakan dalam penelitian ini adalah The posstest only control group design dengan 3 perlakuan.

Populasi yang digunakan pada penelitian ini adalah siswa Kelas 11 IPA MAN Tempursari-Ngawi.Teknik pengambilan sampel yang digunakan adalah simple random sampling, yaitu pengambilan sampel secara acak sederhana, dimana setiap individu atau unit anggota dari populasi mempunyai kesempatan yang sama untuk dipilih menjadi sampel. Dalam hal ini sampel yang digunakan adalah 45 siswa dari 11 IPA 1, 11 IPA 2 dan 11 IPA 3 MAN Tempursari - Ngawi.

Variabel bebas dalam penelitian ini adalah penggunaan model Open inquiry dan Guided inquiry. Variabel terikat dalam penelitian ini adalah kemandirian belajar siswa dan hasil belajar siswa berfikir tingkat tinggi. Hasil belajar yang diukur dalam penelitian ini adalah kemampuan berfikir tinggi yang diukur dengan soal-soal C4,C5,C6. Sedangkan kemandirian belajar siswa yang di ukur adalah semangat belajar, percaya diri, bertanggung jawab, kontrol diri, inisiatif diri, mampu mengambil keputusan, sifat ungin tahu, hasrat bersaing dengan menggunakan angket pembelajaran, hasil observasi dan wawancara.

Prosedur penelitian dalam penelitian ini adalah sebagai berikut: tahap persiapan, peneliti melakukan observasi terhadap pembelajaran biologi di MAN Tempursari dengan teknik pengamatan dan wawancara kepada guru biologi, membuat instrumen penelitian berupa tes esai sebanyak 5 soal yang bertujuan untuk mengukur hasil belajar berfikir tingkat tinggi dimulai dari C4-C6. menyusun angket pembelajaran untuk mengukur kemandirian siswa, kemandirian siswa yang di ukur adalah hasrat bersaing, semangat belajar, mampu mengambil keputusan, percaya diri, bertanggung jawab, sifat ingin tahu, menyusun lembar observasi dan wawancara siswa selama di kelas (lembar ini digunakan untuk mengukur kemandirian siswa), menyusun perangkat pelaksanaan pembelajaran (RPP) Open inquiry dan Guided inquiry materi jaringan hewan dan lembar kerja siswa (LKS). Tahap pelaksanaan pembelajaran model Open inquiry dan Guided inquiry dalam penelitian ini adalah sebagai berikut:

1. Sebelum pelaksanaan pembelajaran, peneliti membagikan lembar observasi. Selama pembelajaran berlangsung, observer mencatat hasil pengamatan kegiatan siswa pada lembar observer yang telah ditentukan oleh peneliti untuk menukur kemandirian belajar awal siswa.

2. Guru melaksanakan tindakan model Open dan Guided inquiry . Adapun langkah-langkahnya berdasarkan sintaks model Open dan Guided inquiry adalah sebagai berikut:

a. Menyajikan masalah,

b. Mengumpulkan dan verifikasi data

c. Melakukan eksperiman,

d. Mengorganisasikan dan membuat penjelasan, 
e. Menganalisis proses inquiry (membuat kesimpulan

3. Guru memberikan soal diakhir pelajaran untuk mengetahui hasil belajar siswa dan memberikan angket pemebelajaran untuk mengukur kemandirian siswa.

Instrument pengumpulan data dalam penelitian ini adalah terdiri dari:

1. Instrument tes berupa soal esaidengan jumlah 5 soal.

2. Instrumen yang digunakan untuk mengetahui kemandirian siswa berupa lembar observasi, wawancara dan lembar angket yang terdiri dari 30 pertanyaan.

Metode pengumpulan data dalam penelitian ini adalah metode angket, meode observasi dan metode wawancara. Setelah diperoleh data kemandirian belajar siswa dan berfikir tingkat tinggi, kemudian dilanjutkan pengujian hipotesa dengan menggunakan uji analisis varians (Anova). Analisis varians yang digunakan adalah analisis varians satu jalan.

\section{HASIL DAN PEMBAHASAN}

\section{Perbedaan Kemandirian Belajar}

Sebanyak 40 siswa dari 45 sampel siswa dikategorikan memiliki kemandirian belajar yang tinggi yaitu $>$ 110 skor rentang kategori tinggi, sementara 5 orang dikategorikan kemandirian belajar sedang $<110$ skor rentang kategori sedang. Skor ideal (kriterium) untuk seluruh item 5 x 30 $=150$. Rata-rata skor perlakuan untuk Open Inquiry adalah 125,53 , Guided Inquiry 119,6 dan kontrol 116.46. Hal ini berarti rata-rata kemandirian siswa berada dalam kategori tinggi. Berdasarkan uji anova bahwa rata-rata penggunaan model pembelajaran memang berbeda dengan demikian kesimpulan yang di dapatkan masing-masing penggunaan model pembelajaran memberikan hasil yang berbeda berdasarkan kemandirian belajar.

Pada pembelajaran Guided inquiry kemandirian siswa cukup tinggi tetapi tidak terlihat secara jelas karena pembelajaran banyak peran dari guru. Sementara pembelajaran dengan kontrol tidak memungkinkan siswa untuk mengeksplor kemampuan dikarenakan pembelajaran hanya berbatas pada ceramah. Hal ini juga di dukung oleh hasil observasi dan wawancara terhadap kemandirian belajar siswa pada siswa Open Inquiry hasil kemandirian belajar $92.85 \%$, guided inquiry 92,85\% dan kontrol $71,43 \%$. Hal ini berarti rata-rata kemandirian belajar berdasarkan observasi lebih tinggi pada perlakuan inquiry baik open maupun guided. Siswa dengan perlakuan open dan guided lebih aktif bertanya dan kritis terhadap suatu permasalahan, mereka juga lebih mampu membuat kesimpulan terhadap suatu permasalahan yang diberikan.

Penerapan model pembelajaran pada masing- masing kelas ternyata mempunyai pengaruh terhadap kemandirian belajar siswa. Penerapan model pembelajaran inquiry mempunyai pengaruh yang lebih besar pada peningkatan kemandirian belajar siswa dari pada penerapan model pembelajaran konvensional. Hal ini sesuai dengan Yuliyanti (2009) yang mengungkapkan bahwa masing-masing metode tersebut mempunyai kelebihan dan kekurangan. 
Tabel.1 Data Skor Kemandirian Belajar

\begin{tabular}{|c|c|c|c|c|c|}
\hline \multicolumn{2}{|c|}{ Open Inquiry } & \multicolumn{2}{|c|}{ Guided inquiry } & \multicolumn{2}{|c|}{ Kontrol } \\
\hline No & Total Skor & No & Total Skor & No & Total Skor \\
\hline 1 & 132 & 16 & 123 & 31 & 111 \\
\hline 2 & 127 & 17 & 132 & 32 & 104 \\
\hline 3 & 126 & 18 & 114 & 33 & 110 \\
\hline 4 & 135 & 19 & 120 & 34 & 114 \\
\hline 5 & 129 & 20 & 115 & 35 & 120 \\
\hline 6 & 124 & 21 & 118 & 36 & 117 \\
\hline 7 & 125 & 22 & 125 & 37 & 130 \\
\hline 8 & 126 & 23 & 115 & 38 & 118 \\
\hline 9 & 128 & 24 & 121 & 39 & 104 \\
\hline 10 & 114 & 25 & 116 & 40 & 121 \\
\hline 11 & 135 & 26 & 119 & 41 & 132 \\
\hline 12 & 129 & 27 & 129 & 42 & 107 \\
\hline 13 & 124 & 28 & 125 & 43 & 120 \\
\hline 14 & 111 & 29 & 113 & 44 & 112 \\
\hline 15 & 118 & 30 & 109 & 45 & 127 \\
\hline \multicolumn{6}{|c|}{ Skor Total $\left(\sum\right)$} \\
\hline \multicolumn{2}{|r|}{1883} & \multicolumn{2}{|c|}{1794} & \multicolumn{2}{|c|}{1747} \\
\hline \multicolumn{6}{|c|}{ Rata-rata } \\
\hline \multicolumn{2}{|c|}{125.53} & \multicolumn{2}{|c|}{119.6} & \multicolumn{2}{|c|}{116.46} \\
\hline
\end{tabular}

Tabel 2. Data Berfikir Tingkat Tinggi

\begin{tabular}{cccccc}
\hline & Open Inquiry & \multicolumn{2}{c}{ Guided inquiry } & \multicolumn{3}{c}{ Kontrol } \\
\hline 1 & 15 & 16 & 16 & 31 & 13 \\
2 & 11 & 17 & 12 & 32 & 12 \\
3 & 14 & 18 & 10 & 33 & 13 \\
4 & 18 & 19 & 17 & 34 & 13 \\
5 & 14 & 20 & 14 & 35 & 11 \\
6 & 17 & 21 & 17 & 36 & 18 \\
7 & 12 & 22 & 13 & 37 & 14 \\
8 & 10 & 23 & 11 & 38 & 10 \\
9 & 14 & 24 & 14 & 49 & 11 \\
10 & 9 & 25 & 16 & 41 & 11 \\
11 & 18 & 26 & 11 & 42 & 11 \\
12 & 12 & 27 & 7 & 43 & 17 \\
13 & 12 & 28 & 13 & 44 & 10 \\
14 & 12 & 29 & 18 & 45 & 10 \\
15 & 5 & 30 & \multicolumn{3}{c}{ Skor Total } \\
\hline \multicolumn{5}{c}{ Rata-rata } \\
\hline \multicolumn{5}{c}{13,4} \\
\hline
\end{tabular}

Tabel 3. Ringkasan Uji Anova Kemandirian Belajar

\begin{tabular}{ccc}
\hline F Hitung & Sig & F Tabel \\
\hline 5.805 & 0.006 & 4.07 \\
\hline
\end{tabular}




\section{Perbedaan Berfikir Tingkat Tinggi}

Berdasarkan data hasil berfikir tingkat tinggi, jumlah nilai tertinggi terdapat pada perlakuan Open Inquiry yaitu 193 dari 15 sampel yang digunakan dalam pembelajaran. Sementara nilai guided inquiry dan kontrol sebesar 189 dan 188. Nilai tertinggi adalah 18 sementara nilai terendah adalah 5 . Sementara berdasarkan uji anova dengan kesimpulan bahwa rata - rata populasi berbeda atau rata - rata penggunaan model pembelajaran memang berbeda.

Berdasarkan skor rata-rata siswa, nilai dengan rata-rata tertinggi pada Guided inquiry. Tetapi jumlah skor total tertinggi terdapat pada Open Inquiry. Pada pembelajaran Open dan Guided hasil yang mereka dapatkan dalam evaluasi soal berfikir tingkat tinggi berdasarkan pengalaman yang mereka dapatkan dalam pembelajaran sementara perlakuan kontrol materi yang di ajarkan oleh guru lebih mendetail sehingga hasil belajar dengan soal berfikir tinggi tidak memiliki rentang nilai yang cukup jauh. Namun demikian pembelajaran dengan menggunakan Open Inquiry dan Guided inquiry

efektif digunakan untuk pembelajaran selain metode konvensional yang banyak ditemukan saat ini.

Ardana (2000) mengemukakan bahwa paradikma belajar yang diinginkan abad pengetahuan adalah belajar berorientasi pada proyek, masalah, penyelidikan, penemuan, dan penciptaan. Inquiry dapat mengajak siswa untuk mampu mengembangkan berbagai hipotesis dalam pikirannya, kemudian mampu berpikir divergen (Suyanto, 2005). Sementara kemampuan berfikir tinggi dapat di ukur dengan menggunakan model pembelajaran yang memungkinkan siswa untuk berfikir kritis, mampu memecahkan masalah, mampu menganalisis serta mengambil keputusan atau kesimpulan seperti pembelajaran inquiry.

\section{KESIMPULAN DAN SARAN}

\section{Kesimpulan}

Berdasarkan penelitian perbedaan model pembelajaran Open Inquiry dan Guided inquiry berdasarkan kemandirian belajar dan berfikir tingkat tinggi, hasil yang didapatkan adalah :

1. Terdapat perbedaan model pembelajaran Open Inquiry dan Guided inquiry berdasarkan kemandirian belajar siswa. Rata-rata skor angket siswa Open Inquiry125,53, Guided inquiry119,6 dan kontol 116,6.

2. Terdapat perbedaan model pembelajaran Open Inquiry dan Guided inquiry berdasarkan berfikir tingkat tinggi

3. Berdasarkan pemberian soal dengan kategori C4, C5 dan C6 skor kelompok Open Inquiry 193, Guided inquiry 189 dan kontrol 188.

4. Berdasarkan hasi lobservasi dan wawancara, siswa dengan pembelajaran Open Inquiry dan Guided inquiry memiliki kemandirian belajar lebih baik daripada perlakuan kontrol.

\section{Saran}

Dari hasil penelitian ini, maka penulis menyampaikan saran bahwa :

1. Pada waktu menerapkan pembelajaran dengan model Open Inquiry dan Guided inquiry hendaknya masalah yang dikemukakan dapat digunakan untuk penelitian atau eksperimen agar hasil yang di dapatkan lebih maksimal.

2. Bagi guru bidang studi khususnya Biologi diharapkan bias menjadikan pembelajaran dengan model Open dan Guided inquiry sebagai salahsatu 
alternatif dalam proses belajar mengajar.

\section{DAFTAR PUSTAKA}

Amin, M. H. 2010. Hasil Belajar Biologi Ditinjau Dari Pembelajaran Inkuiri dan Kemandirian Belajar Pada Kelas VII SMP N 16 Surakarta Tahun Ajaran 2008/2009. Skripsi Sarjana Pendidikan, Program Studi Pendidikan Biologi Universitas Sebelas Maret, Surakarta.

Ardana, W. 2000. Reformasi Pembelajaran Menghadapi Abad Pengetahuan. Makalah disajikan dalam Seminar dan Diskusi Panel Nasional Teknologi Pembelajaran $V$. Diselenggarakan oleh Program Studi TEP PPS UM bekerjasama dengan Ikatan Profesi Teknologi Pendidikan Indonesia (IPTPI) Cabang Malang, 7 Oktober 2000.

Puspawati, Nanik. 2011. Penerapan Model Pembelajaran ProblemBased-Learnig dipadukan dengan strategi Inquiri Untuk Peningkatan Kemampuan Pemecahan Masalah dan Hasil Belajar Biologi. Skripsi Sarjana Pendidikan. Jurusan Pendidikan Biologi Universitas Muhammadiyah Malang, Malang

Rosnawati. 2009. Enam Tahapan Aktivitas Dalam Pembelajaran Matematika Untuk Mendayagunakan Berpikir Tingkat Tinggi Siswa. Seminar Nasional dengan tema : "Revitalisasi MIPA dan Pendidikan MIPA dalam rangka Penguasaan Kapasitas Kelembagaan dan
Profesionalisme Mепијu WCU” tanggal 16 Mei 2009

Sanjaya, Wina. 2010. Strategi Pembelajaran Berorientasi Standar Proses Pendidikan. Prenada Media Group: Jakarta.

Sudarmin, 2012. Meningkatkan Kemampuan Berpikir Tingkat Tinggi Mahasiswa Melalui Pembelajaran Kimia Terintegrasi Kemampuan Generik Sains. Varia Pendidikan, No. 1 Vol 24, Juni 2012 Hal. 97-103

Sugiyono. 2010. Metode Penelitian Pendidikan. Alfabeta . Bandung

Sumarmo, Utari. 2013. Kemandirian Belajar: Apa, Mengapa, Dan Bagaimana Dikembangkan Pada Peserta Didik. FMIPA UPI, Bandung.

Tahar, I. \& Enceng. 2006. Hubungan Kemandirian Belajar Dan Hasil Belajar Pada Pendidikan Jarak Jauh. Jurnal Pendidikan Terbuka dan Jarak Jauh, No. 2 Vol. 7, September 2006 Hal. 91-101

Trianto. 2006. Model Pembelajaran Terpadu dalam Teori dan Praktek. Jakarta : Prestasi Pustaka Publisher

Trianto. 2010. Model Pembelajaran Terpadu : Konsep, Strategi dan Implementasinya dalam Kurikulum Tingkat Satuan Pendidikan (KTSP). Jakarta : PT. Bumi Aksara

Utami. 2012. Pengaruh Strategi Pembelajaran Guided inquiry Terhadap Keterampilan Proses Sains Ditinjau dari Gaya Belajar Siswa Kelas VIII SMP Negeri 1 
JATEN Tahun pelajaran 2011/2012. Skripsi Sarjana Pendidikan. Jurusan Pendidikan Biologi Universitas Sebelas Maret, Surakarta
Yuliati, L. 2013. Efektivitas Bahan Ajar Ipa Terpadu Terhadap Kemampuan Berpikir Tingkat Tinggi Siswa SMP. Jurnal Pendidikan Fisika Indonesia, No. 9 Vol 1 Januari 2013 Hal 53-57 